\title{
Effect of riboflavine deficiency on bone marrow function and protein metabolism in baboons. Preliminary report
}

\author{
By HENRY FOY, ATHENA KONDI AND VERTISTINE MBAYA \\ The Wellcome Trust Research Laboratories, Nairobi, Kenya
}

(Received 2 December 1963-Accepted I8 March 1964)

Reduction in total serum protein content, medullary erythroid hypoplasia, anaemia and abnormal excretion of amino acids and their catabolites are frequent complications of marasmus and kwashiorkor (Foy \& Kondi, 1958a,b, 196I; Foy, Kondi \& Macdougall, I961; Kondi, Mehta \& Foy, 1962; Kondi, Mehta, Foy \& Mbaya, I962; Neame \& Naude, 1961; Kho-Lien-Keng, 1957; Kho-Lien-Keng \& Tumbelaka, I960; Neame I962). In these conditions the hypoplasia occurs early in the disease in association with infection and with the appearance of giant proerythroblasts in the marrow. Spontaneous remission takes place when the infection clears. Alternatively the hypoplasia may occur later when the clinical condition of the patient is improved and the serum proteins are normal. Then there is no association with giant proerythroblasts or infection and the patients respond to treatment with riboflavine or prednisone (Kondi, Macdougall, Foy, Mehta \& Mbaya, 1963; Kondi, Mehta \& Foy, 1962).

To investigate these forms of aplasia and the response to treatment more thoroughly the conditions were produced in baboons by means of dietary deficiency of riboflavine.

After the animals had been for 2-10 months on the deficient diet, there was a profound fall in serum protein content and a medullary erythroid hypoplasia; skin lesions appeared, and there was abnormal amino-aciduria involving disordered tryptophan metabolism. Terminally, many of the animals became apathetic and some anorexic. Three died, one from anaemia, one from an overdose of anaesthetic, and of one, which had an aplastic marrow with red cell precursors accounting for $10.5 \%$ of its nucleated marrow cells (normal $34 \%$, range $28-40 \%$ ), the cause of death was not obvious but adrenal insufficiency was suspected.

\section{EXPERIMENTAL \\ Animals and diet}

Six female and four male baboons (Papio anubis) of ages ranging from $1 \frac{1}{2}$ to 5 years were given an experimental basal diet consisting, for each baboon, of:

$\begin{array}{ll}\text { Casein or soya bean, vitamin-free } & 80 \mathrm{~g} / \text { day } \\ \text { Sucrose, vitamin-free } & 260 \mathrm{~g} / \text { day } \\ \text { Fats (Mazola Oil) (maize oil) } & 20 \mathrm{ml} / \text { day } \\ \text { Mineral salts (see Table } \mathrm{I} \text { ) } & 17.5 \mathrm{~g} / \text { day } \\ \text { Vitamins } & \text { As given in Table I }\end{array}$


Each animal therefore had approximately $1000-1600 \mathrm{kcal}$ daily according to appetite, of which about $20 \%$ was from protein, about $72 \%$ from carbohydrates and about $5 \%$ from fats.

The amounts of vitamins and minerals offered daily are shown in Table $\mathbf{I}$.

Four of the animals were given $150 \mathrm{mg}$ galactoflavine daily in addition to their riboflavine-deficient diet. This substance is an antagonist of riboflavine and is known to accelerate the production of riboflavine deficiency and erythroid aplasia (Lane, Mengel \& Doherty, 1960; Alfrey \& Lane, 1963). In these galactoflavine-fed animals the erythroid aplasia developed $3^{-5}$ weeks earlier than in those not given galactoflavine. 'The animals were kept in separate circular cages, $1 \mathrm{~m}$ in diam. and $2.4 \mathrm{~m} \mathrm{high}$, with special floors arranged for collection of faeces and urine, and they had had no previous treatment.

Table I. Daily allowances of minerals and vitamins for the baboons

\begin{tabular}{ll}
\multicolumn{2}{c}{ Mineral salts } \\
$\mathrm{NaCl}$ & $2.4 \mathrm{~g}$ \\
$\mathrm{~K}_{2} \mathrm{HPO}_{4} \cdot 3 \mathrm{H}_{2} \mathrm{O}$ & $6.9 \mathrm{~g}$ \\
$\mathrm{Ca}_{2} \mathrm{H}_{2}\left(\mathrm{PO}_{4}\right)_{2} \cdot 4 \mathrm{H}_{2} \mathrm{O}$ & $1.4 \mathrm{~g}$ \\
$\mathrm{MgSO}_{4} \cdot 7 \mathrm{H}_{2} \mathrm{O}$ & $2.0 \mathrm{~g}$ \\
$\mathrm{CaCO}_{3}$ & $4.3 \mathrm{~g}$ \\
$\mathrm{Fe}\left(\mathrm{C}_{6} \mathrm{H}_{5} \mathrm{O}_{7}\right)_{3} \cdot 6 \mathrm{H}_{2} \mathrm{O}$ & $0.36 \mathrm{~g}$ \\
$\mathrm{KI}$ & $11 \mathrm{mg}$ \\
$\mathrm{MnSO}_{4} \cdot 4 \mathrm{H}_{2} \mathrm{O}$ & $5 \mathrm{mg}$ \\
$\mathrm{ZnCl}_{2}$ & $3 \mathrm{mg}$ \\
$\mathrm{CuSO}_{4} \cdot 5 \mathrm{H}_{2} \mathrm{O}$ & $4 \mathrm{mg}$
\end{tabular}

Vitamins

\begin{tabular}{|c|c|}
\hline $\begin{array}{l}\text { Thiamine yydrochloride } \\
\text { Pyridoxine hydrochloride }\end{array}$ & $\begin{array}{l}\text { I } \mathrm{mg} \\
\mathrm{I} \mathrm{mg}\end{array}$ \\
\hline Cyanocobalamin & I $\mu \mathrm{g}$ \\
\hline Folic acid & I $\mathrm{r}$ \\
\hline p:intothenate & $3 \mathrm{mg}$ \\
\hline acid & $5 \mathrm{mg}$ \\
\hline Asc & $25 \mathrm{r}$ \\
\hline Choline chloride & $50 \mathrm{mg}$ \\
\hline Inositol & $100 \mathrm{mg}$ \\
\hline -aminobenzoic acid & $100 \mathrm{mg}$ \\
\hline itamin A & $.000 \mathrm{i} . u$ \\
\hline
\end{tabular}

\section{Laboratory investigations}

Bone marrow biopsy, haematological and chemical examinations on blood and twodimensional chromatography for tryptophan metabolites in the urine were done weekly.

Blood was taken from the femoral vein, and marrow from either the sternum or the iliac crest. Twenty-four $h$ specimens of urine were collected uncontaminated with stools by a special funnel arrangement attached to the individual cages.

Marrow smears were made in the usual manner and stained with Leishman and Giemsa stains and the red cell precursors were estimated as a percentage of the total nucleated cell population.

Marrow haemosiderin was measured by the direct method (Rath \& Finch, 1948; Wallerstein \& Pollycove, 1958). Absolute eosinophil cciunts were done by the method of Dacie (1956).

Haemoglobin was measured spectrophotometrically by the cyanomethaemoglobin method and the packed cell volume by a microhaematocrit technique.

Serum proteins were determined by the biuret method (Gornall, Bardawill \& David, I949). The albumin was salted out with $27.2 \%$ sodium sulphate in the warm to avoid carrying over $\alpha_{1}$-globulin into the albumin fraction thus giving falsely high albumin values. The globulins were separated by low-voltage paper electrophoresis using 
barbiturate buffer of $8.6 \mathrm{pH}$, ionic strength 0.075 . Calculations were done by the square-counting technique from which Gaussian curves were built (Wallner, I955; Grassmann \& Hannig, 1954). The agreement between the chemical and the electrophoretic albumin measurements was usually within $0.1-0 \cdot 2 \mathrm{~g} / \mathrm{I} 00 \mathrm{ml}$.

Tryptophan metabolites in the urine were measured either chemically or by twodimensional ascending chromatography, using butanol-acetic acid and isopropanolammonia as solvents (Smith, I960; Charconnet-Harding, Dalgliesh \& Neuberger, 1953). The papers, when dried, were sprayed with Ehrlich's reagent or sulphanilic acid. Xanthurenic acid was determined quantitatively by the method of Rosen, Lowy \& Sprince (195I).

Serum folic acid levels were measured with Lactobacillus casei and Streptococcus faecalis, but only those values obtained with $L$. casei are given.

Serum vitamin $\mathrm{B}_{12}$ levels were measured with Euglena gracilis.

Serum cholesterol was measured by the method of Abell, Levy, Brodie \& Kendall (1952).

\section{RESULTS}

Clinical signs. After 5-8 months on the riboflavine-deficient diet, six animals developed gross skin lesions; three had bloody diarrhoea; in one instance there was vomiting and three animals had a reduced water intake. All of them eventually became anorexic, asthenic, anaemic and lost weight.

Weight changes. The mean maximum weight of the animals before commencing the deficient diet was $1 \mathrm{I} \cdot 3 \mathrm{~kg}$ (range $5 \cdot 5-20.4 \mathrm{~kg}$ ); the mean minimum weight on the deficient diet was $8.6 \mathrm{~kg}$ (range $4 . \mathrm{I}-13.6 \mathrm{~kg}$ ). The weight variations are shown in Table 2.

\section{Table 2. Weight variations of the baboons}

$\begin{array}{cccc}\text { Weight on } & \begin{array}{c}\text { Maximum } \\ \text { weight } \\ \text { attained } \\ (\mathrm{kg})\end{array} & \begin{array}{c}\text { Minimum } \\ \text { weight on } \\ \text { riboflavine- } \\ \text { deficient diet } \\ (\mathrm{kg})\end{array} \\ \begin{array}{c}\text { Baboon no. } \\ \text { 1 }\end{array} & 8.2 & 9.6 & 7.3 \\ 2 & 8.2 & 16.0 & 10.5 \\ 3 & 16.4 & 20.4 & 13.6 \\ 4 & 13.6 & 13.6 & 10.4 \\ 5 & 9.6 & 10.8 & 8.7 \\ 6 & 9.1 & 10.8 & 9.1 \\ 7 & 9.1 & 9.1 & 8.2 \\ 8 & 4.6 & 5.5 & 4.1 \\ 9 & 10.4 & 10.5 & 8.2 \\ 10 & 5.9 & 6.4 & 6.4\end{array}$

Skin. Six animals developed gross para-hyperkeratosis or seborrhoeic dermatitis affecting the face, nose, eyebrows, eyelids and armpits and in the males the scrotum and penis. These signs appeared in from 5 to 8 months after the introduction of the deficient diet; three animals had less severe skin signs (Pl. I). These skin changes were not associated with deficiency of vitamin $A, D$ or $C$, since each animal received 4000 i.u. vitamin $A$ and 400 i.u. vitamin D daily; $1.6 \mathrm{mg}$ ascorbic acid/100 kcal diet 
were also given daily. The skin signs cleared rapidly and completely when riboflavine was given and reappeared when it was again omitted from the diet.

Blood and marrow. All ten animals developed an absolute or relative (see below) erythroid hypoplasia accompanied by anaemia in from 4 to 8 months after they began eating the riboflavine-deficient diet. In three of these, infection was probably an accessory factor as indicated by increased white blood cell counts, myelocytes in the marrow or clinical signs such as diarrhoea. In six animals the hypoplasia was definitely due to deficiency of riboflavine and recovered when it was given. One died with a hypoplastic marrow (red cell precursors $10.5 \%$ ) and a high white cell count; a postmortem revealed nothing else of significance.

There was little change in the myeloid series unless there was an infection; the thrombocytes were frequently reduced. No giant proerythroblasts (Kho-Lien-Keng \& Tumbelaka, I960), or multi-nucleated red cell precurisors were found, such as occur in animals on a vitamin E-deficient diet (Porter, Fitch \&: Dinning, 1962). Giant-stabcells were present in four animals and developed during the course of an infection. Megaloblasts were never seen in spite of decreases in serum folate values and low serum vitamin $B_{12}$ levels.

Five to eight days after riboflavine had been added to the diet or given parenterally, there was a dramatic increase in the number of red cell precursors which sometimes rose from $4 \%$ to more than $70 \%$. Prednisone given by mouth similarly stimulated erythropoiesis. When riboflavine was again removed from the diet, or prednisone was withheld, the number of red cell precursors fell, rising again when treatment was re-started. The same responses of the erythroid marrow occur in the aplastic or hypoplastic anaemia or marasmus and kwashiorkor in children when riboflavine or prednisone is given (Foy et al. 1961; Kondi, Mehta \& Foy, I962).

Haemoglobin. The mean haemoglobin value before the introduction of the dietary regimen was $14^{\cdot 1} \mathrm{~g} / 100 \mathrm{ml}$ (range $12^{\prime} 3^{-16} \cdot 7$ ). On the riboflavine-deficient diet it fell continuously over a period of 2-4 months to a mean of $6.4 \mathrm{~g} / 100 \mathrm{ml}$ (range $3.7-9.9$ ). The haemoglobin level rose slowly when riboflavine was given, returning to normal after about 3-6 weeks. With prednisone the increase in haemoglobin was more gradual perhaps because of changes in blood volume (Kennedy \& Gilbertsen, 1957).

In some instances the haemoglobin level fell whilst that of the red cell precursors remained unchanged or fell with that of the haemoglobin. In other instances the percentage of red cell precursors remained stable whilst the haemoglobin concentration fell, indicating a relative erythroid hypoplasia. When the haemoglobin and red cell precursor values declined together, the hypoplasia was more obvious. 'The mean corpuscular haemoglobin concentration before the riboflavine-deficient diet was given was $3 \mathrm{I} \cdot 2 \%$ (range $30-34 \%$ ). During the deficiency it fell to $27 \cdot 4 \%$ (range $25-30 \%$ ), rising again when riboflavine was added to the diet to $31 \cdot 6 \%$ (range $31-33 \%$ ). Riboflavine- and pyridoxine-responding anaemias have been previously described in man (Foy \& Kondi, $1953 a, b$, I $95^{8} a, b$ ).

Haemosiderin was present in the marrow of all the animals at the beginning of the experiment either as clumps or pepper-like granules; during active blood regenera- 
tion it was reduced. The absolute eosinophil count fluctuated widely and seemed to be associated with the presence of the skin lesions and the presence of infection.

Weight loss and serum proteins. Weight loss was a fairly constant feature in all the animals. In some it was accompanied by loss of appetite-a common sign of riboflavine deficiency. The mean weight before riboflavine was omitted from the diet was $I \mathrm{I} \cdot 3 \mathrm{~kg}$ (range $5.5-20.4 \mathrm{~kg}$ ). At the height of the deficiency it fell to a mean of $8.6 \mathrm{~kg}$ (range $4.1-13.6 \mathrm{~kg}$ ). Reduction in the total serum proteins, taking from 2 to 8 months, occurred in all the baboons, and the values sometimes reached extremely low levels (Table 3).

Table 3. Variations in haemoglobin, serum protein levels and xanthurenic acid excretion in urine of two baboons given a diet with or without ribofluvine

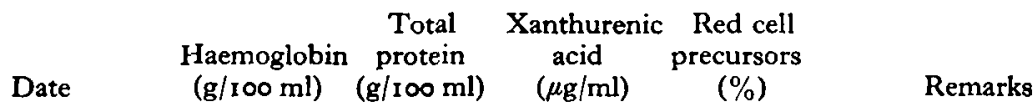

\begin{tabular}{|c|c|c|c|c|c|}
\hline \multicolumn{6}{|c|}{ First animal } \\
\hline 21. ix. 62 & 13.9 & $8 \cdot 1$ & 0 & 40 & Control period \\
\hline 1. xii. 62 & $14 \cdot 0$ & $8 \cdot 2$ & 0 & 49 & \\
\hline 13. ii. 63 & 10.5 & $6 \cdot 8$ & $12 \cdot 5$ & 23 & $\begin{array}{l}\text { 15. xii. } 62 \text {, riboflavine } \\
\text { withdrawn from diet }\end{array}$ \\
\hline $\begin{array}{l}\text { 19. ii. } 63 \\
\text { 26. ii. } 63\end{array}$ & $\begin{array}{l}9 \cdot 4 \\
8 \cdot 4\end{array}$ & $\begin{array}{l}7 \cdot 4 \\
6 \cdot 2\end{array}$ & $\begin{array}{c}+ \\
20 \cdot 0\end{array}$ & $\begin{array}{l}25 \\
18\end{array}$ & \\
\hline 5. iii. 63 & $7 \cdot 4$ & 4.9 & $45^{\circ}$ & 12 & $\begin{array}{l}\text { 5. iii. } 63 \text {, riboflavine } \\
\text { added to diet, } \\
60 \mathrm{mg} \text { for } 6 \text { days }\end{array}$ \\
\hline 27. iii. 63 & $8 \cdot 7$ & $\begin{array}{l}5.4 \\
6 \cdot 0\end{array}$ & $\begin{array}{l}15 \cdot 0 \\
0\end{array}$ & $\begin{array}{l}52 \\
38\end{array}$ & \\
\hline 17. iv. 63 & 10.2 & $\begin{array}{l}0.0 \\
7.0\end{array}$ & 0 & 30 & \\
\hline $\begin{array}{l}\text { 23. v. } 63 \\
\text { vii. } 63\end{array}$ & $\begin{array}{l}11.9 \\
12.6\end{array}$ & $7 \cdot 9$ & $\circ$ & 25 & \\
\hline \multirow{2}{*}{\multicolumn{6}{|c|}{ Second animal }} \\
\hline & & & & & \\
\hline 26. ix. 62 & $14 \cdot 8$ & $6 \cdot 9$ & ० & 32 & Control period \\
\hline I3. iii. 63 & 16.7 & $7 \cdot 6$ & o & 30 & \\
\hline 15. v. 63 & $15 \cdot 6$ & $4 \cdot 8$ & o & 28 & $\begin{array}{l}\text { 15. iii. 63, riboflavine } \\
\text { withdrawn from diet }\end{array}$ \\
\hline 18. vi. 63 & $14 \cdot 6$ & $3 \cdot 9$ & $12 \cdot 0$ & 30 & \\
\hline I. vii. 63 & 13.5 & $4 \cdot 2$ & 18.0 & 25 & \\
\hline 15. vii. 63 & $12 \cdot 6$ & $4 \cdot 0$ & $62 \cdot 0$ & II & \\
\hline 22. vii. 63 & 114 & $4 \cdot 3$ & $30 \cdot 0$ & 18 & \\
\hline 8. viii. 63 & $9 \cdot 0$ & $4 \cdot 0$ & $22 \cdot 0$ & 10 & \\
\hline
\end{tabular}

The normal mean total serum protein level for baboons is $7.0 \mathrm{~g} / 100 \mathrm{ml}$ (range $5^{\circ}$ 8.2) (Foy, Kondi \& Mbaya, unpublished work). In animals at the height of the riboflavine deficiency the mean was $4 \cdot 2 \mathrm{~g} / \mathrm{r} 00 \mathrm{ml}$ (range $3 \cdot 2-5 \cdot 7$ ). The albumin fraction was always more reduced than the globulin fraction, thus changing the albumin: globulin ratio.

Tryptophan metabolism. That there is some upset in tryptophan metabolism in baboons on a riboflavine-deficient diet and in children with marasmus and kwashiorkor is indicated by the presence of abnormal tryptophan metabolites in the urine. This may be due to alteration in some metabolic pathway of tryptophan or to a differential block in some enzymic system. 
The only abnormal metabolite of tryptophan that was consistently excreted in the urine of the riboflavine-deficient baboons was xanthurenic acid, which appeared I-4 months after commencing of the riboflavine-deficient diet in seven out of nine of the animals. In Table 3 are given the figures for two representative animals showing changes in xanthurenic acid levels before and after ribollavine was introduced into the diet, compared with haemoglobin and protein variations.

At the beginning of the experiment there was no santhurenic acid in the urine. After 3 months of riboflavine deficiency the mean xanthurenic acid content was I I $\mu \mathrm{g} / \mathrm{ml}$ (range $7^{-1} 3 \mu \mathrm{g} / \mathrm{ml}$ ). It steadily increased until at the height of the deficiency the mean value was $49 \mu \mathrm{g} / \mathrm{ml}$ (range $20-75 \mu \mathrm{g} / \mathrm{ml}$ ). When riboflavine or prednisone was added to the diet it fell to a mean of $12 \mu \mathrm{g} / \mathrm{ml}$ (range $3-23 \mu \mathrm{g} / \mathrm{ml}$ ), ultimately disappearing (Table 3 ).

Riboflavine-deficient animals loaded with 3-hydroxykynurenine doubled their output of xanthurenic acid, which fell again $24 \mathrm{~h}$ after loading. If 3 -hydroxykynurenine was given with prednisone to the deficient batoons there was no immediate decrease in xanthurenic acid content, but $24 \mathrm{~h}$ later it fell to almost nil.

Folic acid and vitamin $B_{12}$. The mean serum folate level before the riboflavinedeficient diet was given was $7.5 \mathrm{ng} / \mathrm{ml}$ (range 6.9-9. $\mathrm{ng} / \mathrm{ml}$ ). After 4 months of riboflavine deficiency the mean fell to $3.5 \mathrm{ng} / \mathrm{ml}$ (range $2.0-4.8 \mathrm{ng} / \mathrm{ml}$ ), although the animals were receiving I $\mathrm{mg}$ folic acid daily. The mean normal level of serum folic acid for man is approximately $8 \mathrm{ng} / \mathrm{ml}$.

Folic acid may participate in xanthurenic acid metabolism through its action in the conversion of formylkynurenine into kynurenine (Junqueira \& Schweigert, 1948), and riboflavine may be involved in folate metabolism. However, in these baboons xanthurenic acid levels in the urine did not follow thcse of the serum folate.

Insufficient serial observations were made of serura vitamin $B_{12}$ levels before the beginning of the experiment. After 3-5 months of ribcflavine-free diet the mean level was $130 \mathrm{pg} / \mathrm{ml}$ with a range of $80-195 \mathrm{pg} / \mathrm{ml}$; the animals were receiving $1 \mu \mathrm{g}$ cyanocobalamin daily. The normal range for man is f:om 150 to $800 \mathrm{pg} / \mathrm{ml}$.

Cholesterol. A few total serum cholesterol estimations were done on both normal and riboflavine-deficient baboons; the range for the former was $80-150 \mathrm{mg} / 100 \mathrm{ml}$ and for the latter $20-45^{\circ} \mathrm{mg} / 100 \mathrm{ml}$. The great increase in the deficient animals may have been associated with a relative deficiency of pyridoxine which in chicks produces an increase in serum and aortic cholesterol (Dam, Kristensen, Nielsen \& Søndergaard, 1958). However, as stated above, the baboons were having adequate pyridoxine.

Treatment. When the haemoglobin, red cell precursors and serum proteins had fallen to what was thought to be a safe minimum level a total of 200-500 mg riboflavine was added to the diet over a period of 3-7 dalys. Alternatively, 200-400 mg prednisone were given by mouth over a period of 2-4 weeks. 


\section{DISCUSSI ON}

Weight change. On being brought from their natural habitat, the mean weight of the baboons was $9.5 \mathrm{~kg}$ (range $4 \cdot 6-16.4 \mathrm{~kg}$ ). After a mixed natural diet in captivity it rose to a mean of $I 1 \cdot 3 \mathrm{~kg}$ (range $5 \cdot 5-20 \cdot 4 \mathrm{~kg}$ ). The mean weight after the riboflavinedeficient diet was given was $8.6 \mathrm{~kg}$ (range $4.1-13.6 \mathrm{~kg}$ ). All the animals were young and actively growing, so that increase in weight in captivity was no doubt partly due to natural growth and better food. The fall in weight on a riboflavine-deficient diet is, therefore, the more significant. There are no growth rate figures available for baboons and it is therefore difficult to assess the significance of the weight changes.

Changes in weight and anorexia were not always correlated since in many animals weight loss occurred while appetite was good. Nor did reduction in serum proteins or haemoglobin follow either loss in weight or loss of appetite. There is a similar lack of correlation between haemoglobin and serum protein levels in marasmus and kwashiorkor (Foy \& Kondi, 1958a) although Ghitis, Piazuelo \& Vitale (1963) have described some association in Cebus monkeys. Bloody diarrhoea no doubt contributed to haemoglobin reduction, but the effect of haemoconcentration in such animals complicated the haemoglobin picture.

Many of these signs, although non-specific, may have been associated with adrenocortical changes (Paschkis, Rakoff \& Cantarow, 1958; Turner, 1959). In our animals, however, the post-mortem revealed no macroscopical or cytological changes in the adrenals.

Skin lesions. The skin lesions were probably not specific for any particular dietary or vitamin lack; similar conditions have been reported in deficiency of vitamin A, D or $\mathrm{C}$ (Griesemer, Frazier \& Blank, 1953; Anonymous, 1963a), and develop in response to a variety of unrelated stimuli (Gillman \& Gillman, 1951).

Lane et al. (1960) and Alfrey \& Lane (1963) have reported skin changes and erythroid aplasia in man given a riboflavine-free diet with galactoflavine, which cleared when riboflavine was given. It seems then that the skin has a limited number of responses to a variety of stimuli.

Marrow. During the experiments the marrow was highly labile. It was only considered hypoplastic if after several punctures done weekly there was a reduction in red cell precursors affecting the early erythroblasts, late erythroblasts and normoblasts. Before there was evidence of riboflavine deficiency the mean red cell precursor rate was $35 \%$ (range $28-40 \%$ ). At the height of the deficiency the mean was $12 \%$ (range $2-24 \%$ ). After administration of riboflavine or prednisone the mean rose to $53 \%$ (range $4 \mathrm{I}-72 \%$ ).

Blood. The reduction in serum proteins occurred slowly and the level improved gradually when riboflavine was added. Jacquot-Armand, Gaudin-Harding, Blum \& Boffa (1963) reported a great increase in the serum $\gamma$-globulin content in rats on a riboflavine-free diet and a fall in serum riboflavine levels but do not mention total serum proteins. The decreases in the level of serum proteins were like those that occur in marasmus and kwashiorkor and which are thought to be due to a low-protein diet. But in these baboons proteins formed $20 \%$ of their dietary intake. As riboflavine was 
the only missing substance it seems that its absence was directly or indirectly responsible for the serum protein changes, which was confirmed by the rise in content of proteins that occurred whenever riboflavine was added to the diet. The mechanism by which riboflavine deficiency produces these changes is under investigation.

Loss of appetite and weight reduction were not correlated with the development of the anaemia (Foy \& Kondi, 1958a) and in some of the animals similar serum protein falls occurred in spite of good appetites. Bender \& Doell (1962) have reported a decrease in plasma protein level in rats on lysine-deficient diets; the lysine content of the food used for our animals was $7.0 \mu \mathrm{g} / \mathrm{g}$ diet.

Cohen (1955, 1956) has shown that during the menstrual cycle in baboons (Papio ursinus) there are reductions in the plasma protein levels which are correlated with the follicular phase of the cycle. The serum protein changes reported in our riboflavinedeficient baboons occurred in both male and non-menstruating female baboons and were usually greater than those noted by Cohen.

Dean \& Whitehead (1963) think that in kwashiorkor the lack of some essential dietary amino acids may be responsible for the inability to form new proteins and suggest that there may be an enzyme deficiency which prevents or diverts normal amino acid metabolism. Since riboflavine functions as an important coenzyme, perhaps its absence may have interfered with amino acid metabolism and protein synthesis.

Tryptophan metabolism. African children with marasmus and kwashiorkor who develop erythroid hypoplasia during the recovery syndrome excrete anthranilic acid and 3 -hydroxyanthranilic acid in their urine even without tryptophan loading. These may or may not disappear when riboflavine, but not prednisone, is given (Altman \& Miller, 1953; Foy et al. 196r; Kondi et al. 1963).

In riboflavine-deficient baboons with similarly low serum proteins and erythroid hypoplasia, anthranilic acid and 3-hydroxyanthranilic: acid were never found, but xanthurenic acid was present in large amounts. This suggests that, in riboflavinedeficient baboons, there is a metabolic block between kynurenine, 3-hydroxykynurenine and 3 -hydroxyanthranilic acid, kynurenine being metabolized to xanthurenic acid. Either riboflavine or corticosteroids wili correct this error; the latter are known to act on tryptophan pyrrolase (Porter, Stoerk \& Silber, I95 I Knox, I95I, 1959; Frieden, Westmark \& Schor, 1961). Hellström \& Vassella (1962) have reported xanthurenic aciduria in infantile spasm and suggest that the kynurenine-3hydroxykynurenine-xanthurenic acid pathway is utilized more in infants during spasms than normally, and consider that this is because the kynureninase enzyme system is impaired owing to deficiency of pyridoxal-5-phosphate. Ogasawara, Yasumichi \& Kotake (1962) consider that reduction in mitochondrial kynurenine transaminase and kynureninase, which occurs in pyridoxine deficiency induced by DL-penicillamine, leads to the accumulation of kynurenine which is then metabolized to xanthurenic acid instead of to 3-hydroxyanthranilic acid. In the xanthurenic aciduria of the baboons deficiency of riboflavine appeared to block the formation of kynurenic, anthranilic or 3 -hydroxyanthranilic acid in much the same way as pyridoxine deficiency is said to do in man and some other animals. Since kynurenic, 
anthranilic, 3 -hydroxy-anthranilic acids and 3 -hydroxykynurenine never appeared in the urine whereas xanthurenic acid did so, it seems that the absence of riboflavine blocked their appearance.

The presence of xanthurenic acid is usually regarded as an approximate indication of pyridoxine deficiency (Anonymous, 1963b; Harmon, Miller, Hoefer, Ullrey \& Luecke, 1963; Beckmann \& Schreiner, 1962), but in our baboons its presence was specifically related to riboflavine deficiency. In rats, riboflavine and vitamin $B_{8}$ deficiency have been shown to decrease urinary quinolinic and nicotinic acid excretion after administration of tryptophan or kynurenine, but not after that of 3-hydroxykynurenine (Henderson, Weinstock \& Ramasarma, 1951; Charconnet-Harding et al. 1953; Knox, 1959; Henderson \& Gholson, 1959; Brown, 1959). These findings and ours in baboons make it appear that pyridoxine and riboflavine both function in the conversion of kynurenine into 3-hydroxykynurenine. As, however, xanthurenic aciduria occurs in a number of different diseases, its presence cannot be regarded as specific or related to the absence of any particular factor, although it is probably an abnormal constituent of urine.

Theron, Pretorius, Wolf \& Joubert (Ig6r) have described xanthurenic aciduria after tryptophan loading in marasmus and kwashiorkor and suggested that deficiency of pyridoxine was the cause. Xanthurenic aciduria occurs in tropical sprue (Sigler, Sheehy, Santini \& Rubini, 1962) without any evidence of either pyridoxine or riboflavine deficiency and the intestinal flora may have been implicated in this condition. There is an increase in xanthurenic acid, anthranilic acid or both in late pregnancy, viral hepatitis, hyperthyroidism, Hodgkin's disease, diabetes, rheumatoid arthritis, tuberculosis, leukaemia, schistosomiasis and other conditions, but increases in kynurenic acid are neither common nor constant (Fleischmajer \& Hyman, 196r; Marver, I96r; Oka \& Leppänen, 1963). In most of these conditions there is little evidence of either pyridoxine or riboflavine deficiency. Xanthurenic aciduria cannot, therefore, be regarded as a specific manifestation of any particular clinical condition.

It seems then that irregularities in tryptophan metabolism may be precipitated by either riboflavine or pyridoxine deficiency or by metabolic upsets, particularly in pregnancy, in which pyridoxine metabolism is associated with hormonal imbalance (Anonymous, 1961; Chiancone, 1962; Delost \& Terroine, 1963).

The presence of incomplete metabolites of tryptophan in the urine in a number of unrelated conditions suggests that its metabolism may be diverted by a variety of factors and lead to the same metabolic end-point (Korbitz, Price \& Brown, i963). Abnormal amino-aciduria with or without tryptophan loading has also been reported in hypoplastic anaemia (Altman \& Miller, 1953; Foy et al. 1961; Kondi, Mehta \& Foy, I962; Kondi, Mehta, Foy \& Mbaya, 1962). It is commoner in infants and young children, especially in those with marasmus and kwashiorkor (Schendel \& Hansen, 1959, 1962; Andrews, 1961). In these diseases it is anthranilic acid and 3-hydroxyanthranilic acid that are present and these disappear when riboflavine is given (Altman \& Miller, 1953; Foy \& Kondi, 1953a,b; Foy et al. 1961). The marrow aplasias in some of these children respond to riboflavine (Foy \& Kondi, 1953 $a, b$; Kondi et al. 1963), but not in others (Altman \& Miller, 1953). Xanthurenic aciduria 
has not so far been reported in the aplasias of marasrnus and kwashiorkor, nor has anthranilic acid or 3-hydroxyanthranilic acid in the aplasias of riboflavine-deficient baboons. In tropical and non-tropical sprue and pancreatogenous steatorrhoea the absorption of the products of intestinal bacterial activity may be a factor in abnormal amino-aciduria (Haverback, Dyce \& Thomas, 1960; Sigler et al. 1962). In such cases antibiotics will alter the amino-aciduria by modifying the flora (Gibson \& McDougall, I961).

\section{SUMMARY}

I. Baboons were fed on an experimental diet adequate in calories, proteins, fats, carbohydrates, mineral salts and all vitamins except riboflavine. After 2-1o months on this diet, the haemoglobin, serum proteins and red cell precursors in the marrow fell to low levels. Xanthurenic acid was consistently found in the urine, an indication of abnormal tryptophan metabolism.

2. Levels of serum proteins, haemoglobin and red cell precursors returned to normal and xanthurenic acid disappeared from the urine when riboflavine was added to the diet or prednisone given by mouth. All the abnormalities reappeared when riboflavine was again withdrawn.

Since riboflavine is an important coenzyme in many metabolic processes, its absence may have interfered with amino acid metabolism and protein synthesis and led to serum protein reduction. Deficiency of riboflavine may produce erythroid hypoplasia, serum protein reduction and upsets in tryptophan metabolism indirectly by deranging corticosteroid production; hence the response to prednisone.

3. Loading the baboons with kynurenine or 3 -hydroxykynurenine increased the output of xanthurenic acid in the riboflavine-deficient animals but no 3 -hydroxyanthranilic or anthranilic acid appeared. If 3 -hydroxykynurenine was given simultaneously with prednisone, there was a decrease in the output of xanthurenic acid only after a lapse of $12 \mathrm{~h}$. The presence of large amounts of xanthurenic acid in the urine indicates a block in the tryptophan metabolic pathway between kynurenine, 3hydroxykynurenine and 3 -hydroxyanthranilic acid which riboflavine or corticosteroids removes. Xanthurenic aciduria is usually regarded as an index of pyridoxine deficiency, but all the animals in this experiment had adequate amounts of this vitamin; there was clear-cut evidence that the xanthurenic aciduria was associated with deficiency of riboflavine and not of pyridoxine.

Riboflavine deficiency may increase the demand for pyridoxine, create a relative deficiency of vitamin $B_{6}$ and thus lead to xanthurenic aciduria. It is unlikely that this occurred in these baboons since they were having adequate quantities of pyridoxine.

4. Marrow erythroid hypoplasia was a constant feature of all the riboflavinedeficient baboons. The thrombocytes were also reduced but not the myelocyte series. Erythroid hypoplasia occurs in infants with marasmus and kwashiorkor and is associated with urinary anthranilic and 3 -hydroxyanthranilic acids and responds, as in baboons, to riboflavine or prednisone. Although erythroid hypoplasia and low levels of serum proteins were present in all the riboflavine-deficient animals, there was no anthranilic or 3 -hydroxyanthranilic acid but only xanthurenic acid. In some animals 
the erythroid hypoplasia was complicated by infections, as frequently happens in children with marasmus and kwashiorkor. Reduction in serum protein levels was not directly correlated with erythroid hypoplasia or with a change in haemoglobin levels either in baboons or in children with marasmus and kwashiorkor.

5. Gross skin lesions developed in the riboflavine-deficient animals but were probably not specific; they cleared when riboflavine was given and reappeared when it was again withdrawn.

6. In spite of adequate dietary folic acid, the serum folate levels fell in all the animals, but megaloblastic anaemia was never present although giant-stab-cells appeared in four animals that had superimposed infections. Serum vitamin $B_{12}$ levels were low compared with those in normal man. When riboflavine was added to the diet the serum folate levels rose. No correlation was found between variations in serum levels of folate and the other blood and urine measurements.

We are very grateful to Professor M. Rachmilewitz of the Hebrew University, Jerusalem, and to Dr D. L. Mollin of the Postgraduate Medical School, London, for the assistance in estimating serum folate and vitamin $B_{12}$.

\section{REFEREN CES}

Abell, L. L., Levy, B. B., Brodie, B. B. \& Kendall, F. E. (1952). F. biol. Chem. 195, 357.

Alfrey, C. P. \& Lane, M. (1963). Blood, 22, 811 .

Altman, K. I. \& Miller, G. (1953). Nature, Lond., 172, 868.

Andrews, B. F. (1 96r). Clin. Proc. Child. Hosp. Wash. 17, 291.

Anonymous (1961). Nutr. Rev. 19, 174.

Anonymous (1963a). Nutr. Rev. 21, 106.

Anonymous (1963b). Nutr. Rev. 21, 89.

Beckmann, R. \& Schreiner, U. (1962). Arch. Kinderheilk. 167, 254.

Bender, A. E. \& Doell, B. H. (1962). Brit. Y. Nutr, 16, 191.

Brown, R. R. (1959). In Sympositum on Tryptophan Metabolism, p. 52. Atlantic City, NJ: American Chemical Society.

Charconnet-Harding, F., Dalgliesh, C. E. \& Neuberger, A. (1953). Biochem. f. 53, 513.

Chiancone, F. M. (I962). Acta vitam., Milano, 2, 49.

Cohen, S. (1955). F. Endocrin. 12, 196.

Cohen, S. (1956). Biochem. J. 64, 286.

Dacie, J. V. (1956). Practical Haematology. London: Churchill.

Dam, H., Kristensen, G., Nielsen, G. K. \& Søndergaard, E. (1958). Acta physiol. scand. 44, 67.

Dean, R. F. A. \& Whitehead, R. G. (1963). Lancet, i, 188.

Delost, P. \& Terroine, T. (1963). Arch. Sci. physiol. 17, 107.

Fleischmajer, R. \& Hyman, A. B. (1961). Arch. Dermat. 84, 563 .

Foy, H. \& Kondi, A. (1953a). F. Path. Bact. 65, 559.

Foy, H. \& Kondi, A. (1953 b). Brit. med. F. i, 1449 .

Foy, H. \& Kondi, A. (1958a). Trans. roy. Soc. trop. Med. Hyg. 52, 46.

Foy, H. \& Kondi, A. (1958b). Blood, 13, 1054.

Foy, H. \& Kondi, A. (1961). Brit. med. F. ii, 1357.

Foy, H., Kondi, A. \& Macdougall, L. (196I). Brit. med. Y. i, 937.

Frieden, E., Westmark, G. W. \& Schor, J. M. (196r). Arch. Biochem. Biophys. 92, 176.

Ghitis, J., Piazuelo, E. \& Vitale, J. J. (1963). Amer. F. clin. Nutr. 12, 452.

Gibson, F. \& McDougall, B. (1961). Aust. 7. exp. Biol. med. Sci. 39, 171.

Gillman, J. \& Gillman, T. (195I). Perspectives in Human Malnutrition. New York: Grune and Stratton.

Gornall, A. G., Bardawill, C. J. \& David, M. M. (1949). F. biol. Chem. r77, 751 .

Grassmann, W. \& Hannig, K. (1954). Klin. Wschr. 32, 838.

Griesemer, R. D., Frazier, C. N. \& Blank, I. H. (1953). Medicine, Baltimore, 32, 293.

Harmon, B. G., Miller, E. R., Hoefer, J. A., Ullrey, D. E. \& Luecke, R. W. (1963). F. Nutr. 79, 269.

Haverback, B. J., Dyce, B. \& Thomas, H. V. (1960). New Engl. F. Med. 262, 754.

Hellström, B. \& Vassella, F. (I962). Acta paediat., Uppsala, 51, 665. 
Henderson, L. M. \& Gholson, R. K. (1959). In Symposium on Tryptophan Metabolism, p. 38. Atlantic City, NJ: American Chemical Society.

Henderson, L. M., Weinstock, I. M. \& Ramasarma, G. B. (195I). F. biol. Chem. 189, 19.

Jacquot-Armand, Y., Gaudin-Harding, F., Blum, J. C. \& Boffa, G. A. (1963). C.R. Acad. Sci., Paris, 256, 2936.

Junqueira, P. B. \& Schweigert, B. S. (1948). F. biol. Chem. 175, 535.

Kennedy, B. J. \& Gilbertsen, A. S. (1957). New Engl. Y. Med. 256, 719.

Kho-Lien-Keng, K. (1957). Blood, 12, r7r.

Kho-Lien-Keng, K. \& Tumbelaka, W. A. J. F. (1960). Ann. paediat., Basel, 194, 257.

Knox, W. E. (1951). Brit. F. exp. Path. 32, 462.

Knox, W. E. (1959). In Symposium on Tryptophan Metabolism, p. 28. Atlantic City, NJ: American Chemical Society.

Kondi, A., Mehta, S. H. \& Foy, H. (1962). Brit. med. F. i, I ro.

Kondi, A., Mehta, S. H., Foy, H. \& Mbaya, V. (1962). Brit. med. Y. i, 725.

Kondi, A., Macdougall, L., Foy, H., Mehta, S. H. \& Mbaya, V. (1963). Arch. Dis. Childh. 38, 267.

Korbitz, B. C., Price, J. M. \& Brown, R. R. (1963). J. Nutr. 80, 55.

Lane, M., Mengel, C. E. \& Doherty, D. J. (1960). Proc. Amer. Soc. clin. Invest. 39, 1004.

Marver, H. S. (1961). F. Lab. clin. Med. 58, 425 .

Neame, P. B. (1962). Brit. med. $\mathcal{~}$. i, 1275.

Neame, P. B. \& Naude, E. E. (1961). Brit. med. F. i, r 539.

Ogasawara, M., Yasumichi, H. \& Kotake, Y. (1962). F. Biochem., Tokyo, 52, r62.

Oka, M. \& Leppänen, V. V. E. (1963). Acta med. scand. 173, 361.

Paschkis, K. E., Rakoff, A. E. \& Cantarow, A. (1958). Clinical Endocrinology, and ed. London: Cassell.

Porter, C. C., Stoerk, H. C. \& Silber, R. H. (195I). Y. biol. Chem. 193, 193.

Porter, F. S., Fitch, C. D. \& Dinning, J. S. (1962). Blood, 20, 47 r.

Rath, C. E. \& Finch, C. A. (1948). F. Lab. clin. Med. 33, 81.

Rosen, F., Lowy, R. S. \& Sprince, H. (195 I). Proc. Soc. exp. Biol., N. Y., 77, 399.

Schendel, H. E. \& Hansen, J. D. L. (1959). S. Afr. med. F. 33, 871 .

Schendel, H. E. \& Hansen, J. D. L. (1962). Э. Pediat. 60, 280.

Sigler, M. H., Sheehy, T. W., Santini, R. \& Rubini, M. E. (r962). Amer. J. med. Sci. $244,197$.

Smith, I. (editor) (1960). Chromatographicand Electrophoretic Techniques. London: William Heinemann.

Theron, J. J., Pretorius, P. J., Wolf, H. \& Joubert, C. P. (1961). J. Pediat. 59, 439.

Turner, C. D. (1959). General Endocrinology. London: Saunders.

Wallerstein, R. O. \& Pollycove, M. (1958). Arch. intern. Med. Ior, 418.

Wallner, A. (1955). Arztl. Forsch. 9, 1/332.

\section{EXPLANATION OF PLATE}

Skin changes in baboons given a riboflavine-deficient diet. (I) Normal baboon; (2) and (3) after 4 months on a riboflavine-deficient diet; $(4)$ and (5) after riboflavine had been added to the deficient diet. 
British Fournal of Nutrition, Vol. 18, No. 3

Plate I
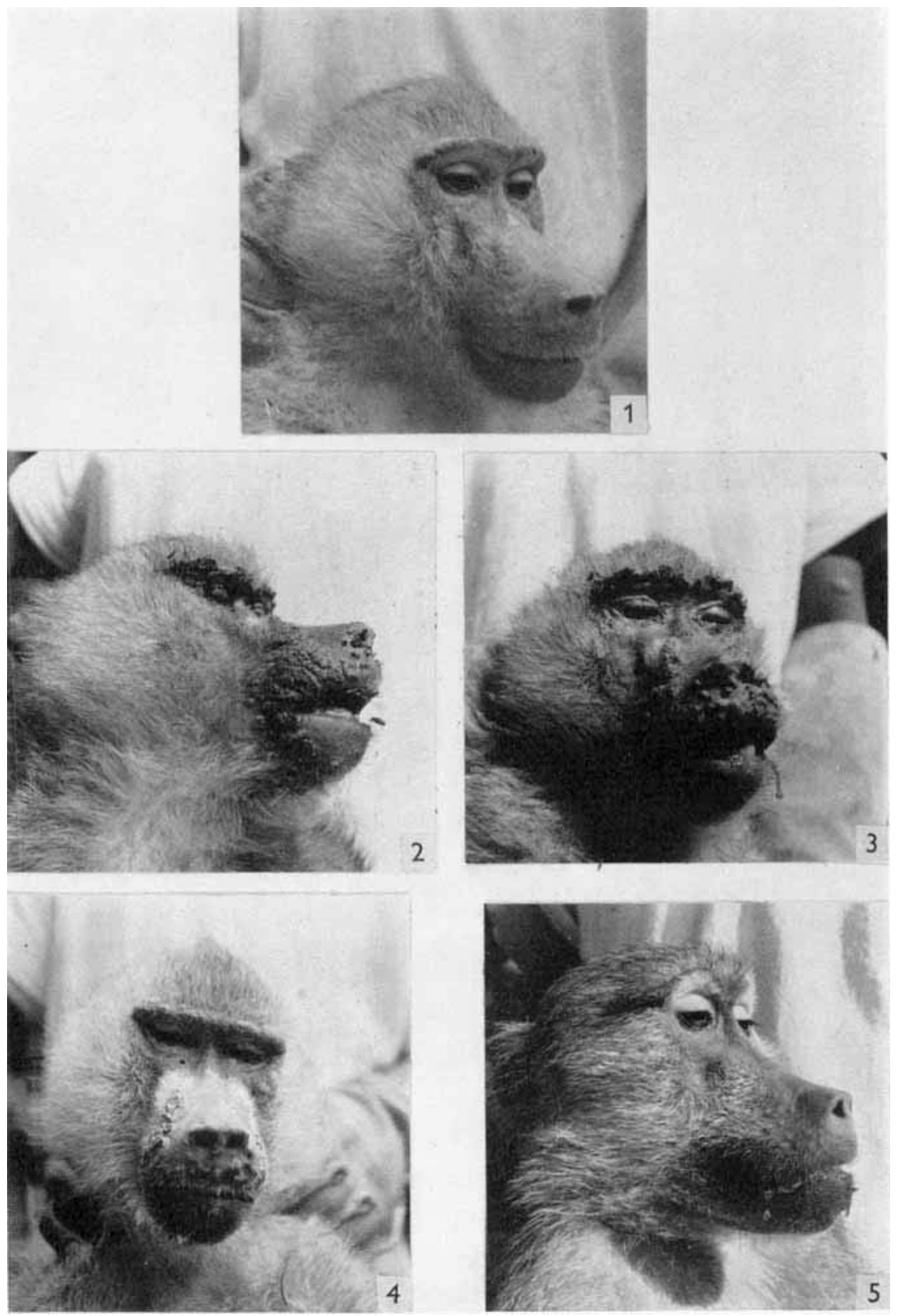

HENRY FOY, ATHENA KONDI AND VERTISTINE MBAYA

(Facing p. 318) 